\title{
THE INFLUENCE OF COMPENSATION AND TRAINING TOWARD WORK DISCIPLINE AND ITS IMPACT ON THE EMPLOYEES' PERFORMANCE IN THE RESEARCH CENTER OF SCIENCE AND TECHNOLOGY (PUSPIPTEK)
}

\author{
Andhi Bharata \\ Management Department, School of Business Management, Bina Nusantara University, \\ Jln. K.H. Syahdan No 9, Jakarta Barat, DKI Jakarta, 11480, Indonesia \\ andhibharata27@gmail.com
}

\begin{abstract}
Background issues that occured in PUSPIPTEK (Research Center of Science and Technology) was the declining of employee performance, low discipline in work such as not obeying the rules, and decreased absenteeism as coming late to the office. The purpose of this study was to determine the effect of compensation on, the effect of training on work discipline, the effect of compensation on employee performance, the effect of training on employee performance, the effect of work discipline on employee performance, and the effect of compensation and training to the work discipline and its impact on employee performance PUSPIPTEK. This research was associative and the measurement scale applied likert scale. The method of analysis used was path analysis and the number of samples in this study was 116 respondents. Based on the result, this study concludes that the compensation and training toward the work discipline has a significant influence on the employees' performance. The empirical findings indicate that in order to improve the employees' performance in PUSPIPTEK need to pay attention on compensation, training, and work discipline.
\end{abstract}

Keywords: compensation, training, work discipline, employees’ performance

\section{INTRODUCTION}

The occurrence of this globalization gives impact on the development of the increasingly modern era. The development of modern era has an impact on the organization or company. They must be more careful and quick in following its development if do not want to left behind, especially in science and technology which has increasingly evolved. The development in science and technology is certainly giving a positive impact in a wide range of information and knowledge, recent discoveries, and advanced technology. As an organization or company, it could harness science and technology in processing the goods and services to make it more effectively and efficiently. In this process necessarily is required human resources to implement them.

Research Center of Science and Technology (PUSPIPTEK) is an area of research which is located in the village Setu, Setu District of South Tangerang City. PUSPIPTEK is a tool in conducting research of targeted and integrated as a determinant of community needs and raise awareness of the role of science and technology in national development. In the region of PUSPIPTEK, there are three non-ministerial government institution, namely BATAN (National Nuclear Energy Agency), BPPT (Agency for the Assessment and Application of Technology), and LIPI (Indonesian Institute of Sciences). These three institutions are located in PUSPIPTEK region that produces variety of researches and technical services in various laboratories. As in the processing of industry sector, there is a national standard laboratory that has become the reference for all measurements in Indonesia. 
Besides that, in the food sector, pharmaceuticals and medical have produced tempe processing technology into milk, ice cream, and extraction of efficacious ingredients for traditional herbal.

PUSPIPTEK is not apart from a few problems that occurred in employees' performance, such as when the employees have been giving appropriate compensation, but in reality, what often happen is the employees who have been compensated by a corresponding amount, it does not affect their discipline in work. Employees still cannot be disciplined at work, such as coming late to work and passing of the deadline to complete the task (a predetermined time). Coming late to work will decrease the employees' performance, and it will cause the working time has reduced from a predetermined time, so employees take more time to complete its work. Besides compensation, PUSPIPTEK also provides regular training each year to its employees to improve their ability and to make employees be disciplined at work. The training that provided by PUSPIPTEK aims to train employees to be responsible and implement existing regulation and to improve the capabilities of the employees. If PUSPIPTEK can provide appropriate compensation and training, it will affect on employees work discipline that resulted in an increasing of employees' performance, so it can help PUSPIPTEK to achieve organizational goals. Based on PUSPIPTEK problems on this research, it is needed further research and to find out the influence of compensation and training toward work discipline and its impact on employees' performance in PUSPIPTEK.

There are several problem identifications, is there any influence of (1) compensation toward employees' work discipline, (2) training toward employees work discipline, (3) compensation toward employees' performance, (4) training toward employees' performance, (5) work discipline toward employees' performance, (6) compensation and training toward work discipline and its impact on the employees' performance in PUSPIPTEK?

Menawhile, the research objectives are to find out (1) the influence of compensation toward employees work discipline, (2) the influence of training toward employees work discipline, (3) the influence of compensation toward employees performance, (4) the influence of training toward employees performance, (5) the influence of work discipline toward employees performance, (6) the influence of compensation and training toward work discipline and its impact on employees performance in PUSPIPTEK.

This research gives benefits for PUSPIPTEK, the employees, and others. The benefits of this research for PUSPIPTEK are (1) to provide information about the influence of compensation and training toward work discipline and its impact on employees' performance in PUSPIPTEK; (2) to provide suggestion to PUSPIPTEK in efforts to improve work discipline through the provision of compensation and training; and (3) to be a reference to provision of compensation and training that can be used in improving employees' performance in PUSPIPTEK.

While for others, this research has benefits, such as (1) to be useful for learning and can be used as a reference for others who want to examine the implementation of the compensation, employees training, and work discipline; (2) the other party can find out how the compensation and training can affect the work disciplines that have an impact on employee performance; (3) to add insight to the reader about PUSPIPTEK.

Compensation is paid to employees in exchange for services that they have contributed to the company (Bangun, 2012). According to R. Wayne Mondy (2014), the compensation is the total remuneration that given to employees as a reward for their services. Hameed et al., (2014) has stated that compensation has the positive impact on employee performance. Compensation is divided into two types; they are financial and non-financial compensation. The services that are donated by employees for their work get rewarded in the form of money, either directly or indirectly. Direct financial compensation is paid tribute in the form of salaries, wages, incentives, and bonuses. Meanwhile, indirect financial compensation is a form of financial rewards that paid indirectly, such as 
social security, medical, insurance, vacation, retirement and other benefits. While non-financial compensation is an award that not given in the form of money, but someone will get satisfaction from the work and the environmental organization. Such compensation may include to organizational policies, qualified managers, fun coworkers, flexible time, and good job distribution (Bangun, 2012).

According to Mathis \& Jackson (2010), training is a process whereby people acquire capabilities to aid in the achievement of organizational goals. So the training is a process whereby an employee can gain the ability to assist in the achievement of organizational goals. Training is a process created by the organization in an effort to improve the quality of its employees in order to work optimally in order to assist the organization in achieving its objectives. Sultana et al., (2012) has stated that in the development of organizations, training plays a vital role in improving performance as well as increasing productivity, and eventually putting companies in the best position to face competition and stay at the top.

Work discipline is a form of the terms that defined and accepted by the employees to comply with existing regulations in an organization so that employees can work in a responsible manner. According to Byars \& Rue (2006), the work discipline is the action that taken against an employee who has violated an organizational rule or whose performance has deteriorated to the point where corrective action is needed. This means that the discipline is an action taken against employees who have violated the rules of the organization or whose performance has deteriorated to the point where corrective action is needed.

Robbins \& Coulter (2005) have said that performance is the work result of individuals or groups in achieving the organization's goals set in accordance with a predetermined period. Group or organization is made up of several individuals so that individual performance will affect the performance of the group or organization. Training and performance are still affecting each other that Awang (2010) has defined that personal training affect job performance (skills and individual capabilities impact on productivity). Assessment of performance (performance appraisal - PA) is the process of evaluating how well employees are doing their jobs when compared with a standard set, and then communicate with employees (Mathis \& Jackson, 2006).

\section{METHODS}

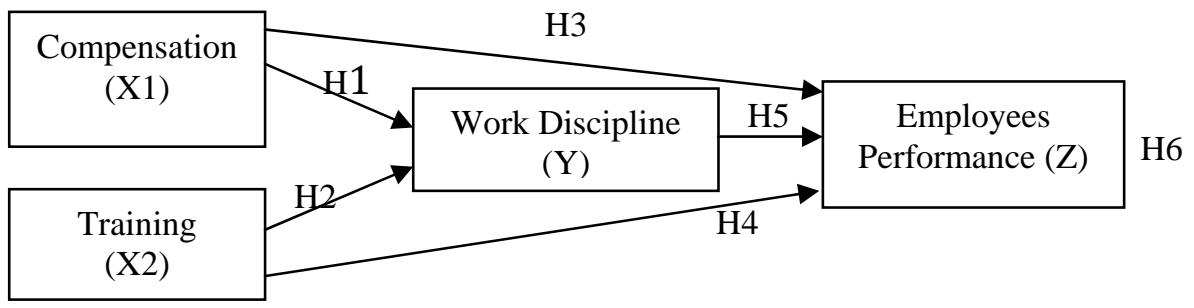

Figure 1 Theoretical Framework

(Source: Author)

The theoretical framework (Figure 1) is based on the following hypotheses with first hypothesis:

Ho: there is no significant influence between compensation and employees work discipline in PUSPIPTEK.

Ha: there is significant influence between compensation and employees work discipline in PUSPIPTEK. 
The second hypothesis is:

Ho: there is no significant influence between training and employees work discipline in PUSPIPTEK.

$\mathrm{Ha}$ : there is significant influence between training and employees work discipline in PUSPIPTEK.

The third hypothesis is:

Ho: there is no significant influence between compensation with employees' performance in PUSPIPTEK.

$\mathrm{Ha}$ : there is significant influence between compensation with employees' performance in PUSPIPTEK

The fourth hypothesis is:

Ho: $\quad$ there is no significant influence between training with employees' performance.

$\mathrm{Ha}$ : there is significant influence between training with employees' performance.

The fifth hypothesis is:

Ho: there is no significant influence between employees work discipline with employees performance in PUSPIPTEK.

Ha: there is significant influence between employees' work discipline with employees' performance in PUSPIPTEK.

The sixth hypothesis is:

Ho: there is no significant influence between compensation and training toward work discipline with the employee's performance.

$\mathrm{Ha}$ : there is significant influence between compensation and training toward work discipline with the employee's performance.

The research design used is associative research to determine the effect of independent variables on the dependent variable through intervening variables as the intermediate variables. The unit of analysis targeted is all of the employees in PUSPIPTEK as much as 162 employees. Sampling technique used in this study is the probability sampling in which everyone who will be sampled will have the same opportunities, while the sample selection is done by simple random sampling method with the purpose to get accurate results although through the randomly selected because the sample has taken already represented a whole population. Then the sample used in this study as much as 116 employees in PUSPIPTEK. Data collection techniques used is trough spread the questionnaire within one week to the study respondents.

The analysis technique used is path analysis by using SPSS version 20. The results of this study can be used by companies to evaluate and make improvements to the compensation, training, and work discipline so that the employees' performance in PUSPIPTEK can be improved. The research design of this article can be seen in Table 1.

Table 1 Research Design

\begin{tabular}{ccccc}
\hline Research Objectives & $\begin{array}{c}\text { Type of Research } \\
\text { Method }\end{array}$ & $\begin{array}{c}\text { Research } \\
\text { Method }\end{array}$ & Unit of Analysis & Time Horizon \\
\hline H1-6 & Associative & Survey & $\begin{array}{c}\text { Individual Employees in } \\
\text { PUSPIPTEK }\end{array}$ & $\begin{array}{c}\text { Cross } \\
\text { Sectional }\end{array}$ \\
\hline
\end{tabular}

Source: Author (2016) 
Operationalization of the variables used in this study is the independent variables, namely compensation (X1) and training (X2) as well as the dependent variable, namely work discipline (Y) and employees performance (Z). Table 2 represents the operationalization of research varaibbles.

Table 2 Operationalization of Research Variables

\begin{tabular}{|c|c|c|c|}
\hline Variable & Dimension & Indicator & $\begin{array}{c}\text { Measurement } \\
\text { Scale }\end{array}$ \\
\hline Compensation (X1) & $\begin{array}{l}\text { Direct Compensation } \\
\text { Indirect Compensation }\end{array}$ & $\begin{array}{l}\text { Salary } \\
\text { Incentive } \\
\text { Protection (insurance and pension } \\
\text { funds) } \\
\text { Allowance } \\
\text { Facility }\end{array}$ & Likert Scale \\
\hline Training (X2) & Training Program & $\begin{array}{l}\text { Infrastructure } \\
\text { Methods and content of training } \\
\text { Training time } \\
\text { Benefits of training }\end{array}$ & Likert Scale \\
\hline Labor Discipine (Y) & $\begin{array}{l}\text { The attitude and } \\
\text { behavior of employees }\end{array}$ & $\begin{array}{l}\text { Frrequency of attendance } \\
\text { Strict adherence to regulations } \\
\text { Strict adherence to labor standards } \\
\text { Work ethic }\end{array}$ & Likert Scale \\
\hline Employees Performance (Z) & $\begin{array}{l}\text { Employees } \\
\text { Performance } \\
\text { Assessment }\end{array}$ & $\begin{array}{l}\text { Number of jobs } \\
\text { Quality of work } \\
\text { Punctuality } \\
\text { Attendance } \\
\text { Ability to work in team }\end{array}$ & Likert Scale \\
\hline
\end{tabular}

Source: Author (2016)

The types of research data are quantitative and qualitative data. The quantitative data is data in the form of its numbers that can be counted and measured the amount to be processed using statistical methods. While qualitative data is the research data that is not a number that nature can not be calculated in the form of information or explanation based on a theoretical approach and logical assessment. The source of research data consists of primary data and secondary data. Data collection techniques that the author uses in this research are both literature study and field study.

\section{RESULTS AND DISCUSSIONS}

After doing steps of validity, reliability, normality, correlation, and path analysis that obtained results of data processing to find out the influence of variable compensation (X1) and training (X2) toward the Work discipline $(\mathrm{Y})$ and their impact on employees performance $(\mathrm{Z})$. It can be seen in Table 3. 
Table 3 Relationship of the Empirical Causal of Variabel $\mathrm{X}_{1}, \mathrm{X}_{2}$, toward $\mathrm{Y}$ to $\mathrm{Z}$

\begin{tabular}{|c|c|c|c|c|}
\hline \multirow{3}{*}{ Influence of Variable } & \multicolumn{2}{|c|}{ Causal Influence } & \multirow{3}{*}{$\begin{array}{c}\text { Residual } \varepsilon_{1} \text { and } \\
\varepsilon_{2}\end{array}$} & \multirow{3}{*}{ Total } \\
\hline & \multicolumn{2}{|c|}{ Indirect } & & \\
\hline & Direct & Through Y & & \\
\hline $\mathrm{X}_{1}$ toward $\mathrm{Y}$ & 0,442 & - & - & 0,442 \\
\hline $\mathrm{X}_{2}$ toward $\mathrm{Y}$ & 0,550 & - & - & 0,550 \\
\hline \multirow{2}{*}{$\mathrm{X}_{1}$ toward Z } & 0,128 & - & - & 0,128 \\
\hline & - & $0,128+(0,442 \times 0,598)$ & - & 0,392 \\
\hline \multirow{2}{*}{$\mathrm{X}_{2}$ toward $\mathrm{Z}$} & 0,270 & - & - & 0,270 \\
\hline & - & $0,270+(0,550 \times 0,598)$ & - & 0,598 \\
\hline $\mathrm{Y}$ toward $\mathrm{Z}$ & 0,598 & - & - & 0,598 \\
\hline $\mathrm{X}_{1} \mathrm{X}_{2} \mathrm{Y}$ toward $\mathrm{Z}$ & 0,812 & - & 0,188 & 1,00 \\
\hline
\end{tabular}

Source: Data Processing (2016)

In overall, the influence of the causal variable compensation (X1) and training (X2) toward work discipline $(\mathrm{Y})$ and their impact on employees' performance $(\mathrm{Z})$ can be described in a model of the complete structure in Figure 2.

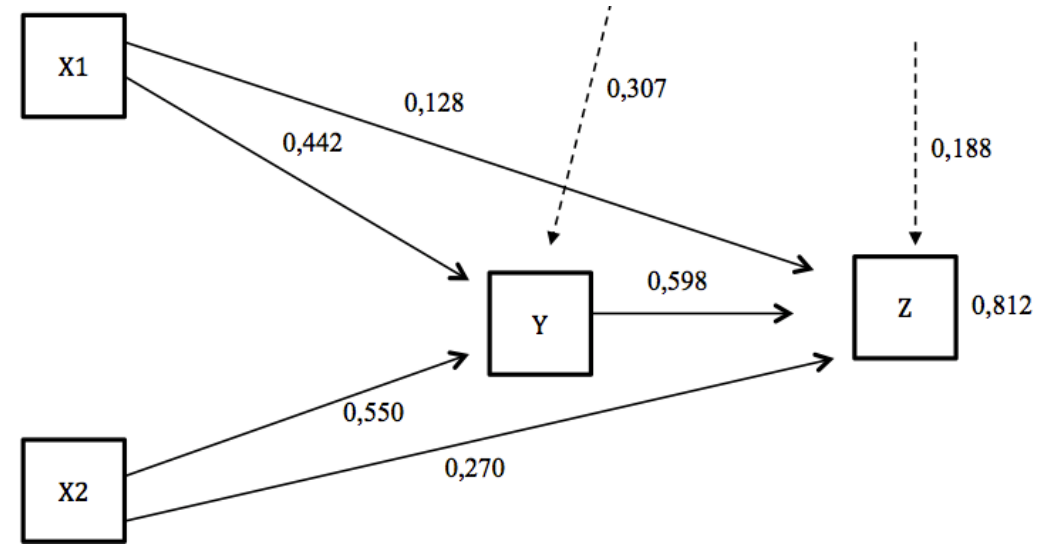

Figure 2 Relationship of the Empirical Causal of Variabel $\mathrm{X}_{1}, \mathrm{X}_{2}$, toward $\mathrm{Y}$ to $\mathrm{Z}$

(Source: Author, 2016)

\section{CONCLUSIONS}

Based on the research and discussion that has been done, the authors obtain the research results that will be used to meet the objectives of this research. On the first objective which is to find out the influence of compensation on work discipline in PUSPIPTEK. It is concluded that the compensation has a significant influence on work discipline in PUSPIPTEK. On the second objective which is to find out the influence of training on work discipline in PUSPIPTEK. It is concluded that training has a significant influence on work discipline in PUSPIPTEK. On the third objective which is to find out the influence of compensation toward employees performance in PUSPIPTEK. It is concluded that the compensation has a significant influence toward employees' performance in PUSPIPTEK. On the fourth objective which is to find out the influence of training toward employees performance in PUSPIPTEK. It is concluded that training has a significant influence toward employees' performance in PUSPIPTEK. On the fifth objective which is to find out the influence of work discipline toward employees performance in PUSPIPTEK. It is concluded that the work 
discipline has a significant influence toward employees' performance in PUSPIPTEK. And on the fifth objective which is to find out the influence of work discipline toward employees performance in PUSPIPTEK. It is concluded that the work discipline has a significant influence toward employees' performance in PUSPIPTEK.

Based on the research and discussion that has been done, it is evident that the compensation, training, and work discipline has a significant influence toward employees performance in PUSPIPTEK. PUSPIPTEK can improve the system of compensation given to employees by increasing the provision of compensation in directly or indirectly. Giving direct compensation can be improved by increasing the salaries of the employees, while the provision of indirect compensation such as health insurance and pension fund guarantees can be repaired so that the employees feel assured by the health and pension funds. Beside that, the facility to support employees in working could be improved in order to assist and meet the needs of employees at work. So that, if when the provision of compensation in directly or indirectly may be given properly, then it will help improve work discipline which impacted on increased employee performance.

PUSPIPTEK can provide an appropriate training that suitable with the needs of employees. The training given to employees can be improved by increasing the number of training for employees, followed by the quality of training itself. The quality of training is intended to provide training that is more helpful and useful, not only increased the number of training, but the quality of the training provision must be considered such as the instructors who provide training and also the appropriate training content that suitable with the needs of employees. This is done because the training has an influence on the work discipline where training is able to provide benefits to employees who were getting more trained in enhance the capabilities, skills, work responsibility, and discipline at work. So the impact on the employees' performance will increase.

PUSPIPTEK also needs to improve work discipline through controlling and supervision of the employees. Employees still have not been able to comply with work rules and to work not in accordance with the ethics of the company. The attendance list of working employees should be considered so that the tardiness in work hours can be minimized and pay attention to the work that must be completed on time. This is done to ensure employees are able to follow and abide the rules at work to make them more disciplined.

\section{REFERENCES}

Awang, A. H., Ismail, R., \& Noor, Z. M. (2010). Training Impact On Employee’s Job Performance: a self evaluation. Ekonomska Istrazivanja/Economic Research, 23(4), 78-90. Retrieved from http://search.proquest.com.

Bangun, W. (2012). Manajemen Sumber Daya Manusia. Jakarta: Erlangga.

Byars, L., \& Rue, L. (2006). Human Resource Management. 8th Edition. USA: McGraw-Hill.

Hameed, A., Ramzan, M., Hafiz, M. K. Z., Zubair, H. M. K., Ali, G., \& Arslan, M. (2014). Impact of compensation on employee performance (empirical evidence from banking sector of Pakistan). International Journal of Business and Social Science, 5(2), 302-309. Retrieved from http://search.proquest.com.

Mathis, R., \& Jackson, J. (2006). Human Resource Management. 10th Edition. USA: Thomson SouthWestern. 
Mathis, R., \& Jackson, J. (2010). Human Resource Management. Thirteenth Edition. South Western: Cengage Learning.

Mondy, R., \& Mondy, J. (2014). Human Resource Management. Thirteenth Edition. London: Pearson.

Robbins, S., \& Coulter, M. (2005). Management. Pearson Prentice Hall.

Sultana, A., Irum, S., Ahmed, K., \& Mehmood, N. (2012). Impact of Training on Employee Performance: a study of telecommunication sector in Pakistan. Interdisciplinary Journal of Contemporary Research in Business, 4(6), 646-661. Retrieved from http://search.proquest.com. 